Opole

\title{
Józefa Piłsudskiego „droga do niepodległości” w świadomości historycznej młodzieży. (Na przykładzie zadań z historii w arkuszach egzaminów zewnętrznych)
}

\begin{abstract}
Abstrakt: Artykuł ukazuje obraz Józefa Piłsudskiego w zadaniach z historii, które przygotowywane zostały na potrzeby ogólnopolskich egzaminów zewnętrznych przez Centralną Komisję Egzaminacyjną. Przeanalizowano zadania z arkuszy gimnazjalnych oraz maturalnych. Analiza wykazała satysfakcjonującą obecność Józefa Piłsudskiego w poleceniach odnoszących się do wydarzeń z I wojny światowej, gdy jego droga do wolnej Polski była już na ostatniej prostej.
\end{abstract}

Słowa kluczowe: Józef Piłsudski, świadomość historyczna młodzieży, arkusze egzaminacyjne.

Abstract: The article present the image of Józef Piłsudski in history exercises prepared for the national Polish internal exams by the Central Examination Commission. An analysis of exercises from junior and high school worksheets revealed that Józef Piłsudski's presence in exercises on events of the First World War, when he was in the home stretch of his way to the independent Poland, is satisfactory.

Key w or d s: Józef Piłsudski, historical awareness of the youth, exams worksheets.

Józef Piłsudski zajmuje jedno z najważniejszych miejsc w historii Polski ${ }^{1}$. Dla jednych to postać pomnikowa, dla innych co najmniej kontrowersyjna. Niezależnie jednak od sympatii czy krytyki, którą wzbudza, od lat jest obecny

${ }^{1}$ Zagadnienie to w syntetyczny sposób przedstawił P. Okulewicz, Józef Piłsudski-między popularnościq a kultem, „Wiadomości Historyczne z Wiedzą o Społeczeństwie” 2006, nr 5, s. 18-28. 
na lekcjach historii w szkołach podstawowych, gimnazjach oraz ponadgimnazjalnych (licea i technika) ${ }^{2}$. To z kolei wpływa na jego wysoka pozycję w kanonie wybitnych Polaków, który od lat powstaje na podstawie badań opinii społecznej ${ }^{3}$. Nie mniej interesujące są w tym kontekście badania świadomości historycznej młodzieży4. Popularność Piłsudskiego można określić również na podstawie liczby ulic, które noszą jego imię oraz instytucji, w tym szczególnie szkół, którym patronuje ${ }^{5}$. W tej sytuacji nie powinno dziwić, że popularność Józefa Piłsudskiego wykracza także poza granice naszego kraju, o czym przekonuja badania dydaktyka historii Adama Suchońskiego, który od lat analizuje szkolne podręczniki do nauczania historii z całego świata w kontekście miejsca i oceny pozycji Polski i Polaków na ich kartach ${ }^{6}$.

W obowiąującej podstawie programowej ${ }^{7}$ Józef Piłsudski jest wymieniony z imienia i nazwiska na poziomie szkoły podstawowej i ponadgimnazjalnej. I tak w szkole podstawowej w podstawie programowej przedmiotu historia i społeczeństwo (klasy IV-VI) znalazł się zapis o treści: „uczeń zbiera informacje o zasługach dla państwa polskiego Józefa Piłsudskiego"8. W klasie I

${ }^{2}$ Przykładowo w podręczniku z 1937 r., przygotowanym dla klasy IV gimnazjum przez Jana Dąbrowskiego, obejmujaccym materiał od 1914 r. do połowy lat trzydziestych, na 97 rycin 15 przedstawia Józefa Piłsudskiego, a 6 - I lub II Brygadę Legionów. Zestawienie na podstawie: J. Durka, Rola postaci historycznych w edukacji - dotychczasowe doświadczenia a „nowa podstawa programowa $z$ historii”, w: Pamięć, kultura, edukacja, red. nauk. A.P. Bieś, M. Chrost, B. Topij-Stempińska, Kraków 2011, s. 126. Problematyce tej pracę poświęciła H. Wójcik-Łagan, Kult bohatera narodowego Józefa Piłsudskiego w szkolnej edukacji historycznej w latach trzydziestych XX wieku, Kielce 2012. Bezpośrednio po II wojnie światowej obraz ten w sposób odgórny został zupełnie zmieniony, a sama postać poddana ostrej krytyce. Więcej zob. B. Jakubowska, Przeobrażenia w szkolnej edukacji historycznej $w$ Polsce $w$ latach 1944-1956, Warszawa 1986, s. 231-286.

${ }^{3}$ Wyniki oraz omówienie badań opinii społecznej, w których pytano o najważniejsze postaci w polskiej historii oraz bezpośrednio o Józefa Piłsudskiego, zob. P. Kusiak, Legenda Józefa Pitsudskiego. Jak w Polsce doby integracji europejskiej interpretować postać Marszatka?, „Colloquium” R. II, 2010, s. 252-253.

${ }^{4}$ Badania w tej materii przez kilkanaście lat prowadził m.in. Janusz Rulka. Wyniki w kontekście kanonu wybitnych Polaków oraz miejsca Józefa Piłsudskiego zob. J. Rulka, Niektóre problemy świadomości historycznej młodzieży, „Zeszyty Naukowe Wyższej Szkoły Pedagogicznej w Bydgoszczy. Studia pedagogiczne" 1990, z. 16, s. 31-31; idem, Przemiany świadomości historycznej mtodzieży, Bydgoszcz 1991, s. 70, 78; idem, Świadomość historyczna młodzieży przełomu tysiacleci - wybrane zagadnienia, w: Z Żywca do Opola. Góral z urodzenia, opolanin z wyboru, red. B. Kubis, Opole 2011, s. 355.

${ }^{5}$ Według danych Głównego Urzędu Statystycznego Józef Piłsudski jest patronem ponad 20 szkół oraz blisko 500 ulic w całej Polsce.

${ }^{6}$ A. Suchoński, Polacy na kartach zagranicznych podręczników do nauczania historii, w: Polska, Europa, świat w szkolnych podręcznikach historii, red. S. Roszak, M. Strzelecka, A. Wieczorek, seria: „Toruńskie Spotkania Dydaktyczne”, t. V, Torun 2008, s. 13-14.

${ }^{7}$ Zob. Rozporządzenie Ministra Edukacji Narodowej z dnia 23 grudnia 2008 r. w sprawie podstawy programowej wychowania przedszkolnego oraz kształcenia ogólnego w poszczególnych typach szkół, DzURP, 2009, nr 4, poz. 17.

8 Ibidem, s. 34. 
ponadgimnazjalnej, w której młodzież (mająca 16-17 lat) zapoznaje się z historią Polski i powszechna obejmujacca okres po 1918 r., widnieje zapis: „oceń wkład Józefa Piłsudskiego w budowę państwa polskiego”. Z kolei na poziomie rozszerzonym historii, który dotyczy jednak tylko kilku procent uczniów szkół ponadgimnazjalnych, bezpośredniego odniesienia do postaci J. Piłsudskiego nie ma. W tym miejscu należy jednak podkreślić, że w podstawie programowej wymienionych trzech etapów edukacyjnych w treściach nauczania - wymaganiach szczegółowych - znajdują się zapisy, które pośrednio sugerują konieczność odwołania do działalności Komendanta. W szkole podstawowej uczeń zobligowany jest np. do wymienienia czynników decydujących o odzyskaniu niepodległości przez Polskę. W gimnazjum znajdujemy punkty mówiące o głównych nurtach polskiego życia politycznego w końcu XIX w.; poglądach zwolenników różnych orientacji politycznych oraz ocenie wysiłku zbrojnego Polaków w czasie I wojny światowej. Z kolei w szkołach ponadgimnazjalnych na poziomie podstawowym wprowadzono treści, zgodnie z którymi uczeń opisuje odrodzenie państwa polskiego, przyczyny i następstwa wojny polsko-bolszewickiej, charakteryzuje ustrój II Rzeczypospolitej, wyjaśnia przyczyny i skutki przewrotu majowego, wymienia charakterystyczne cechy rządów sanacji oraz charakteryzuje główne kierunki polityki zagranicznej międzywojennej Polski. W rozszerzeniu uczeń porównuje programy polskich partii politycznych na przełomie XIX i XX w., omawia polskie orientacje polityczne oraz działalność polskich formacji wojskowych w czasie I wojny światowej, opisuje proces kształtowania terytorium II Rzeczypospolitej, rozpoznaje cechy ustroju w oparciu o konstytucje z 1921 i 1935 r., wyjaśnia przyczyny kryzysu demokracji parlamentarnej oraz przyczyny i konsekwencje przewrotu majowego. Z postacią J. Piłsudskiego wiąże się również wyjaśnienie uwarunkowań polityki zagranicznej II Rzeczypospolitej.

Przytoczone powyżej zapisy z obowiąującej w roku szkolnym 2016/2017 podstawy programowej wskazuja, że w polskiej szkole uczniowie wielokrotnie mają okazję zetknąć się z postacią Józefa Piłsudskiego, w tym także w kontekście jego aktywności polityczno-wojskowej w czasie I wojny światowej. Nie brakuje również pomysłów na szczegółowe omówienie z młodzieżą jego życia i działalności na lekcjach historii i społeczeństwa - dziedzictwa epok, który to przedmiot od roku szkolnego 2013/2014 jest realizowany w klasach II i III szkół ponadgimnazjalnych. Zauważmy, że dotyczy to uczniów, którzy nie wybrali rozszerzenia z historii. Jedna z nich przedstawiła Hanna Wójcik-Łagan, podkreślając, że pokazanie uczniom losów i doświadczeń takich postaci, jak Józef Piłsudski, jest nie tylko sposobnością zbliżenia ich

\footnotetext{
${ }^{9} \mathrm{~W}$ tym miejscu należy podkreślić, że tak w jednym, jak i drugim przypadku postać Józefa Piłsudskiego została zestawiona z osobą Romana Dmowskiego, co oznacza, że uczniowie szkoły podstawowej powinni zebrać informacje o zasługach obydwu przywódców dla państwa polskiego (szkoła podstawowa) oraz ocenić ich wkład w jego budowę (szkoły ponadgimnazjalne).
} 
do historii, ale także niepowtarzalną okazją uruchomienia mechanizmów myślenia historycznego ${ }^{10}$.

W procesie przekazywania wiedzy historycznej młodzieży kluczową rolę odgrywa nauczyciel. Jego pasja, kreatywność oraz czas, który poświęca uczniom, w istotny sposób decydują o szkolnych i pozaszkolnych sukcesach uczniów ${ }^{11}$. Nawet najlepszy nauczyciel potrzebuje jednak wsparcia w procesie dydaktycznym. Od lat najpopularniejszy i najważniejszy element tej pomocy stanowi podręcznik. W tym miejscu jego roli i znaczenia nie będę szerzej omawiać, a jedynie wskażę kilka szczególnie wartościowych pozycji z bogatej literatury przedmiotu ${ }^{12}$. Jak wspomniałem, podręcznikowy obraz Józefa Piłsudskiego to ważne kryterium oceny jego popularności nie tylko $\mathrm{w}$ Polsce, ale także w innych krajach. Zagadnienie to było już wielokrotnie analizowane przez dydaktyków historii w kontekście opracowań z okresu międzywojennego, jak i czasów Polski Ludowej ${ }^{13}$. Również najnowsze książki szkolne, tj. wydane po 1989 r., zostały przeanalizowane w kontekście obecności Józefa Piłsudskiego na ich kartach ${ }^{14}$. Dotychczas nie podjęto jednak analizy obrazu bohatera artykułu w zadaniach z historii, przygotowywanych na potrzeby ogólnopolskich egzaminów zewnętrznych. Warto podkreślić, że wszystkie arkusze dostępne są na stronie internetowej Centralnej Komisji

${ }^{10}$ H. Wójcik-Łagan, Spory a dynamika dziejów. Rola postaci historycznych w „Historii i spoteczeństwie. Dziedzictwie epok”, w: „Historia i społeczeństwo. Dziedzictwo epok”. Edukacja historyczna $w$ szkole ponadgimnazjalnej po 2013 roku, red. nauk. M. Fic, Katowice-Bielsko-Biała 2012, s. 213, 222-228.

${ }^{11}$ Literatura przedmiotu dotycząca roli i miejsca nauczyciela w procesie nauczania - uczenia się historii jest bardzo bogata. Zob. m.in.: Nauczyciel historii. Ku nowej formacji dydaktycznej, red. M. Kujawska, Poznań 1996.

12 A. Zielecki, Role i funkcje podręcznika historii, Rzeszów 1984; J. Maternicki, C. Majorek, A. Suchoński, Dydaktyka historii, Warszawa 1994, s. 342-353; Podręcznik historii-perspektywy modernizacji, red. M. Kujawska, Poznań 1994; Przeszłość w szkole przyszłości. Materiały Ogólnopolskiej Konferencji Naukowej „Podręcznik historii dla szkoty XXI wieku”. Częstochowa 20-22 V 1997, red. J. Walczak, A. Zielecki, Częstochowa 1997; A. Zielecki, Wprowadzenie do dydaktyki historii, Kraków 2007, s. 298-306; E. Chorąży, D. Konieczka-Śliwińska, S. Roszak, Edukacja historyczna w szkole. Teoria i praktyka, Warszawa 2008, s. 162-171; Wspótczesna dydaktyka historii. Zarys encyklopedyczny dla nauczycieli $i$ studentów, red. J. Maternicki, Warszawa 2004, s. 266-273; M. Bieniek, Dydaktyka historii. Wybrane zagadnienia, Olsztyn 2009, s. 72-88.

${ }^{13}$ Zob. H. Składanowski, „Od uwielbienia do negacji” - Józef Piłsudski w podręcznikach historii w szkole powszechnej (podstawowej) w II RP $i$ okresie stalinowskim PRL, „Wiadomości Historyczne z Wiedzą o Społeczeństwie” 2006, nr 5, s. 30-38.

${ }^{14}$ Zob. A. Suchoński, Postać Józefa Piłsudskiego $w$ podręcznikach szkolnych, w: Józef Pitsudski i jego wspótpracownicy, red. A. Suchoński, Opole 1999, s. 139-149; M. Białokur, Józef Piłsudski i jego rola $w$ tworzeniu niepodlegtościowego ruchu wojskowego na kartach wybranych podręczników szkolnych, w: Zwiazek Strzelecki „Strzelec” - organizacja spoteczno-wychowawcza. Między tradycjq a wspótczesnościa, red. A. Adamczyk, Zelów 2006, s. 165-183; A. Suchoński, M. Białokur, Przewrót majowy Józefa Piłsudskiego w podręcznikach szkolnych, „Wiadomości Historyczne z Wiedzą o Społeczeństwie” 2007, nr 3, s. 17-40. 
Egzaminacyjnej (https://www.cke.edu.pl). Niniejszą analizę podzieliłem na dwie części: w pierwszej przeanalizowałem zadania z arkuszy gimnazjalnych, w drugiej - maturalnych. Pominąłem zadania ze sprawdzianu po klasie VI szkoły podstawowej, gdyż analiza ich zawartości pokazała, iż pomimo odwołania się w kilku przypadkach do treści stricte historycznych, w żadnym z nich nie było odniesienia do postaci Józefa Piłsudskiego.

Powszechne ocenianie zewnętrzne w polskim systemie oświatowym zostało wprowadzone w 2002 r. - sprawdzian po klasie VI szkoły podstawowej oraz egzamin po klasie III gimnazjum. W 2005 r. system objął wszystkich uczniów trzyletnich liceów, a w 2006 r. - czteroletnich techników ${ }^{15}$. Jednak egzamin maturalny, który w szerokim zakresie sprawdza wiedzę oraz umiejętności historyczne uczniów i jednocześnie stanowi podstawę przyjęcia na wybrane studia wyższe, nie jest obowiązkowy i zdaja go tylko uczniowie, którzy zadeklarowali historię jako przedmiot egzaminacyjny. Wszystkie egzaminy zewnętrzne maja charakter pisemny. Taka formuła obowiązuje od początku pomimo kilku zmian kształtu samego egzaminu, jak i wymogów programowych ${ }^{16}$.

Pierwsze pytanie dotyczące postaci Józefa Piłsudskiego w arkuszu gimnazjalnym obejmujacym wiedzę i umiejętności z przedmiotów humanistycznych (język polski, historia i wiedza o społeczeństwie) pojawiło się na egzaminie w 2011 r. ${ }^{17} \mathrm{~W}$ zadaniu nr 22 uczniowie mieli odwołać się do wiedzy na temat wydarzeń z dziejów walki Polaków o wolność i wskazać, że Tadeusz Kościuszko, Jan Henryk Dąbrowski oraz Józef Piłsudski zasłużyli na miano patriotów. W odpowiedzi winni uwzględnić czas podanych wydarzeń ${ }^{18}$. Za poprawną odpowiedź uczniowie otrzymywali maksymalnie 3 pkt, podczas

${ }_{15}$ B. Anusiewicz-Działak, Matura z historii w 2005 roku, „Wiadomości Historyczne” 2003, $\mathrm{nr}$ 5, s. 36-41; eadem, Informator o maturze 2005, „Wiadomości Historyczne” 2004, nr 1, s. 53-55. W latach 2002-2004 uczniowie mieli możliwość wybrania na egzaminie z historii „starej” lub „nowej” formuły matury. Jak pokazały ich wybory, do czego w znacznym stopniu przyczyniły się nieodpowiedzialne decyzje polityków „grających ze względów politycznych egzaminem maturalnym”, w ogromnej większości uczniowie zdawali egzamin w „starej formule”, tj. pisali rozprawkę na jeden z kilku zaproponowanych tematów. Znikoma liczba zdających egzamin w nowej formule w skali kraju, poniżej promila, zwalnia nas z analizy zadań w tych arkuszach, gdyż w żaden sposób nie przełożyły się na kształtowanie obrazu Józefa Piłsudskiego w odniesieniu do jego działalności w latach I wojny światowej. $\mathrm{Na}$ ten temat zob. G. Chomicki, Historia powróci do zdrowia, czyli nie reformujmy reformy, „Wiadomości Historyczne” 2005, nr 1, s. 51; B. Jakubowska, Metodologia w sojuszu z egzaminem maturalnym, „Wiadomości Historyczne” 2006, nr 1, s. 30-36; M. Białokur, J. Piłat, K. Stecka, Historia $i$ WOS na maturze, czyli pedagoga szkietko i oko, „Wiadomości Historyczne" 2007, nr 2, s. 13-24.

${ }^{16}$ E. Choraży, D. Konieczka-Śliwińska, S. Roszak, op. cit., s. 297-301.

17 Egzamin przeprowadzono 12 IV 2011 r. Przystapiło do niego 418763 uczniów w 7031 gimnazjach w całej Polsce, z czego 645 to szkoły publiczne, a 581 niepubliczne.

18 Arkusz. Egzamin w klasie trzeciej gimnazjum z zakresu przedmiotów humanistycznych, s. 8, https://www.cke.edu.pl/images/stories/0001_Gimnazja_2011/hum/gh-1-112.pdf (dostęp: 20 XII 2016). 
gdy w całym arkuszu można było uzyskać w sumie 50 pkt. Zadanie ułożono zgodnie z drugim obszarem standardów, obejmującym tworzenie własnego tekstu, sprawdzenie umiejętności formułowania argumentów uzasadniających podane stanowisko oraz wyrażania opinii. I tak w skali kraju poziom wykonania zadania ${ }^{19}$ wyniósł 0,20 . Zadanie to okazało się najtrudniejsze $\mathrm{w}$ całym arkuszu $^{20}$. Zgodnie z kluczem uczniowie, aby uzyskać maksymalna liczbę punktów, musieli poprawnie wskazać czas zdarzeń, które potwierdzały, że każda z podanych postaci zasłużyła na miano patrioty. Aby dostać punkt, wystarczyło podać czas i nazwę wydarzenia, które świadczyło o patriotyzmie danej postaci. Poprawne wskazanie czasu i zdarzeń, potwierdzające, że dwie wymienione postaci zasłużyły na miano patrioty, gwarantowało 2 pkt. I odpowiednio informacja o jednej postaci to 1 pkt. Egzaminatorzy sprawdzający arkusze otrzymali od CKE wskazówki o tym, jakie odpowiedzi można uznać za poprawne. Przykładowo: „Józef Piłsudski - był Naczelnym Wodzem w wojnie polsko-ukraińskiej w l. 1918-1919 i wojnie polsko-bolszewickiej w l. 1919-21 oraz inicjatorem wyprawy kijowskiej w 1920 r.; współtworzył organizacje paramilitarne: w 1908 r. Zwiąek Walki Czynnej, w 1914 r. 1 Kompanię Kadrową i Polską Organizację Wojskowa; od 1914 r. był komendantem I Brygady Legionów walczącej przeciwko rosyjskiemu zaborcy; w 1917 r. doprowadził do tzw. kryzysu przysięgowego, w wyniku czego został aresztowany i osadzony w twierdzy magdeburskiej" ${ }^{21}$. Jako przykłady konkretnych, możliwych, dobrych i złych odpowiedzi uczniowskich wskazano z kolei: „Piłsudski był genialnym dowódca, wybitnym strategiem i politykiem. Jemu zawdzięczamy "cud nad Wisłą” i „Józef Piłsudski był komendantem Legionów Polskich we Włoszech, walczył bohatersko u boku Napoleona w czasie wyprawy na Rosje" ${ }^{22}$.

Kolejne zadanie, w którym pojawiła się postać Józefa Piłsudskiego w kontekście jego „drogi do niepodległości”, odnajdujemy w arkuszu gimnazjalnym z 2015 r. ${ }^{23} \mathrm{~W}$ tym miejscu odnotujmy, że od 2012 r., co było konsekwencja

${ }_{19}$ Poziom wykonania zadania oblicza się dzieląc liczbę punktów uzyskanych przez liczbę punktów możliwych do uzyskania. Może on przybierać wartości w przedziale od 0 do 1 . Im współczynnik jest bliższy 1 , tym zadanie łatwiejsze dla uczniów, co wskazuje, że lepiej opanowali oni daną umiejętność. Poziom wykonania zadania możemy również wyrazić w procentach (np. 0,68 to $68 \%$ ).

${ }^{20} \mathrm{~W}$ części humanistycznej egzaminu gimnazjalnego uczniowie otrzymali średnio $25,31 \mathrm{pkt}$ na 50 pkt możliwych do zdobycia. Tworzenie własnego tekstu sprawiło im większą trudność niż czytanie i interpretacja tekstów kultury, gdyż za zadania tego typu dostali $40 \%$ możliwych do uzyskania punktów, podczas gdy za czytanie i interpretację $-61,5 \%$.

${ }^{21}$ Egzamin gimnazjalny 2011. Część humanistyczna. Klucz punktowania zadań. Kwiecień 2011, s. 4, https://www.cke.edu.pl/images/stories/0001_Gimnazja_2011/hum/klucz_punktowania.pdf (dostęp: 20 XII 2016).

${ }^{22}$ Ibidem, s. 5.

${ }^{23}$ Egzamin przeprowadzono 21 IV 2015 r. Przystapiło do niego 350557 uczniów w 6830 gimnazjach w całej Polsce, z czego 6084 to szkoły publiczne, a 746 niepubliczne. 
nowej podstawy programowej z 2008 r., uczniowie zdawali egzamin gimnazjalny w nowej formule. W efekcie wprowadzonych wówczas zmian, które obowiązywały także w 2016 r., egzamin składał się z sześciu części, a pierwsza z nich obejmowała blok zadań z historii i wiedzy o społeczeństwie ${ }^{24}$. Wracając do wspomnianego pytania, które w arkuszu oznaczono numerem 20, odnotujmy, że miało ono zupełnie inny kształt od zadania z 2011 r., gdyż tym razem wykorzystano tekst źródłowy:

Żołnierze! Wśród powszechnej bierności naszego społeczeństwa wypadki dziejowe zaskoczyły Polaków, zostawiając ich bez określonych decyzji, bez możliwości jednolitego i silnego postępowania. Koniecznym było, by najśmielsi i najenergiczniejsi wzięli na swoje barki odpowiedzialność, inicjatywę rzucenia iskry na proch. Tę iskrę rzuciliście, dając przykład innym, jako przodownicy walki narodu polskiego o niepodległość ojczyzny. Obecnie naród burzyć się zaczyna i nie chce nas zostawić samotnymi, tak jak byliśmy dotychczas. W Krakowie zawiązał się Naczelny Komitet Narodowy (NKN - organizacja polityczna utworzona w sierpniu 1914 roku przez polityków galicyjskich w Krakowie) ze wszystkich stronnictw polskich, który ma wystawić Legiony Polskie do walki z Rosją ${ }^{25}$.

Tekst celowo nie został opatrzony żadnym opisem, gdyż zadanie polegało na dokończeniu zdania: „Powyższy tekst jest fragmentem...” Uczniowie wybierali właściwą odpowiedź spośród czterech podanych propozycji: A. rozporządzenia Rady Regencyjnej o obowiązku służby wojskowej; B. manifestu wydanego w imieniu cesarza Niemiec i cesarza Austro-Węgier; C. rozkazu Józefa Piłsudskiego do oddziałów Pierwszej Kompanii Kadrowej; D. odezwy Ignacego Jana Paderewskiego do Polaków służących w armii francuskiej. W zadaniu sprawdzano w ramach wymagań ogólnych „Analizę i interpretację historyczną, a w odniesieniu do wymagań szczegółowych - zagadnienie „Sprawa polska w I wojnie światowej” oraz umiejętność oceny przez uczniów „wysiłku zbrojnego Polaków”26. Udzielenie poprawnej odpowiedzi, czyli wskazanie, że „Powyższy tekst jest fragmentem rozkazu Józefa Piłsudskiego do oddziałów Pierwszej Kompanii Kadrowej”, okazało się dla większości zdających dużym problemem. Świadczy o tym fakt, iż poziom wykonania zadania wyniósł 0,40, czyli tylko 40\% uczniów odpowiedziało

${ }^{24}$ Pozostałe części egzaminu to arkusze z języka polskiego, przedmiotów przyrodniczych (biologia, chemia, fizyka i geografia), matematyki oraz wybranego przez uczniów języka nowożytnego zdawanego na poziomach podstawowym i rozszerzonym.

${ }^{25}$ Arkusz. Egzamin w klasie trzeciej gimnazjum. Część 1. Historia i wiedza o społeczeństwie, s. 17, https://www.cke.edu.pl/images/_EGZAMIN_GIMNAZJALNY/Arkuszeegzaminacyjne/2015/Historia_i_wiedza_o_spoleczenstwie/ARKUSZ_GH-HX1-152.pdf (dostęp: 20 XII 2016).

${ }^{26}$ Egzamin w klasie trzeciej gimnazjum w roku szkolnym 2014/2015. Część 1. Historia i wiedza o społeczeństwie. Zasady oceniania rozwiązań zadań, Kwiecień 2015, s. 7, https://www. cke.edu.pl/images/_EGZAMIN_GIMNAZJALNY/Arkuszeegzaminacyjne/2015/odpowiedzi/ historia_i_wos/Zasady_oceniania_GH-H12451U.pdf (dostęp: 20 XII 2016). 
poprawnie. Był to jeden $\mathrm{z}$ trzech najniższych wyników w arkuszu, który zawierał 25 zadań $^{27}$.

Jak widać z powyższych przykładów, postać Józefa Piłsudskiego w zadaniach zamieszczonych w arkuszach gimnazjalnych w latach 2002-2016 nie była nadmiernie eksponowana. Moim zdaniem nie oznacza to jednak marginalizacji bohatera. Niepokojące sa jednak wyniki uzyskane przez uczniów. W przypadku zadania zamieszczonego w arkuszu z 2015 r. po części można to wyjaśnić tym, że materiał dotyczący I wojny światowej znajduje się na końcu podstawy programowej dla klasy III, podczas gdy egzamin odbywa się w kwietniu i część nauczycieli mogła mieć problem z jego realizacją blisko trzy miesiące przed zakończeniem roku szkolnego. Jeżeli faktycznie tak było, stanowi to kolejny argument $\mathrm{w}$ dyskusji nad niezbyt fortunnym ustaleniem terminu egzaminów w kwietniu, zamiast po zakończeniu roku szkolnego. Należy mieć tylko nadzieję, że z tych doświadczeń wnioski wyciagną autorzy kolejnych reform oświatowych i sprawdzian lub egzamin kończący szkołę podstawowa, który po raz pierwszy zaplanowano w nowej formule w 2019 r., odbędzie się w drugiej połowie czerwca, a więc po zakończeniu całego cyklu nauki przez uczniów klas VIII.

Zewnętrzny egzamin maturalny z historii na przestrzeni lat 2002-2016 kilka razy zmieniał swój kształt. Zawsze jednak materiał, który uczniowie musieli opanować, obejmował okres walki Polaków o niepodległość w czasie I wojny światowej. Po raz pierwszy zadanie, w którym odwołano się do postaci Józefa Piłsudskiego, pojawiło w arkuszu podstawowym w 2007 r. Zadaniem uczniów było przyporządkowanie podpisów do fotografii przedstawiających znane postacie historyczne ${ }^{28}$. Zamieszczony w zadaniu nr 25 materiał ukazywał J. Piłsudskiego na warszawskim pomniku w pobliżu Grobu Nieznanego Żołnierza. Pomnik wykonano według projektu rzeźbiarza Tadeusza Łodziany. Odsłonięto go w 1995 r. Pozostałe fotografie przedstawiały: pomnik Janusza Korczaka na cmentarzu żydowskim w Warszawie, warszawski pomnik gen. Józefa Sowińskiego oraz pomnik Tadeusza Kościuszki na Wawelu w Krakowie ${ }^{29}$.

${ }^{27}$ Osiagnięcia uczniów kończących gimnazjum w 2015, s. 57, https://www.cke.edu.pl/images/ _EGZAMIN_GIMNAZJALNY/Informacje_o_wynikach/Sprawozdanie_z_egzaminu_gimnazjalnego_2015.pdf (dostęp: 20 XII 2016).

${ }^{28}$ W maju 2007 r. do matury obowiązkowej przystapiło 365090 uczniów, z czego historię jako przedmiot obowiązkowy zdawany na poziomie podstawowym pisało 21901 . Łącznie maturę z historii zdawało 57514 osób. Różnice w liczbach zdających wynikały z kilku opcji zdawania egzaminu, które mogli wybierać uczniowie, tj. jako przedmiot obowiąkowy na poziomie podstawowym lub też podstawowym i rozszerzonym, czy też jako egzamin dodatkowy, który mógł być zdawany tylko na poziomie rozszerzonym. Zob. Osiagnięcia maturzystów w roku 2007. Sprawozdanie z egzaminu maturalnego, s. 20, https://www. cke.edu.pl/images/_EGZAMIN_MATURALNY_OD_2015/Informacje_o_wynikach/2007/ sprawozdanie_ogolne_a.pdf (dostęp: 20 XII 2016).

${ }^{29}$ Arkusz. Egzamin maturalny z historii. Poziom podstawowy, maj 2007, s. 21, https://www. cke.edu.pl/images/stories/mat2_07/his_pp.pdf (dostęp: 20 XII 2016). 
W komentarzu CKE po sprawdzeniu matur czytamy, że zadanie nie sprawiło trudności zdającym. Maturzyści rozpoznawali bez większych problemów wybitne postaci zwiąane z dziejami Polski. Do najczęściej poprawnie wskazywanych należeli Józef Piłsudski i Tadeusz Kościuszko. Zadanie prawidłowo wykonało 74\% uczniów ${ }^{30}$.

W 2008 r. w arkuszu z poziomu podstawowego uczniowie mieli do przeanalizowania fragment tekstu $O$ powstaniu 1863 r., autorstwa Józefa Piłsudskiego:

Siła spisku 1830 r. była minimalną. [...] Nikt ze spiskowych nie wyszedł na górę, nikt z nich nie został wodzem dalszej akcji [...]. Cała starszyzna wypowiedziała się przeciwko nim, wszyscy się od nich chowali, jak od zarazy. [...] Jakżeż inną jest siła spisku w 1863 r. Rozkaz, przez jego władze wydany, jest bezapelacyjnie spełniony, tysiące ludzi zbiera się tylko dlatego, że nakazano [...] stanąć pod sztandarem. [...] Spisek 1863 r. przewyższajacy wielokrotnie swą siłą i potęgą spisek 1830 r., szukał sił szlachetnych, wrzących w narodzie, chciał znaleźć oparcie o wewnętrzną całość moralna, o wytrzymałość całej masy ludzi $[\ldots]^{31}$.

Na podstawie powyższego fragmentu uczniowie mieli podać dwie różnice, które autor dostrzegał między działaniami spiskowymi z 1830 i 1863 r. Jako poprawne odpowiedzi zdających wymieniono ocenę, według której Józef Piłsudski uznał, że spisek w 1830 r. przygotowywali ludzie, którzy nie byli gotowi do objęcia przywództwa nad powstaniem i nie oparli swojej działalności na całym społeczeństwie, a w 1863 r. przywódcy powstania odwołali się do całego społeczeństwa i cieszyli się dużym autorytetem, przez co mogli objaćc władzę. Ponadto spisek w 1863 r. miał większy zasięg i siłę oddziaływania (niż spisek w 1830), a jego przywódcy cieszyli się większym autorytetem. Z kolei jako przykładową błędną odpowiedź podano, że w 1830 r. dysponowaliśmy dobrze wyszkoloną armią Królestwa Polskiego, a w 1863 r. nie było polskiej armii czy też, że w 1830 r. społeczeństwo odchodziło od powstania, natomiast w 1863 szły do niego tysiące. Z zdaniem poradziło sobie 62\% zdajacych, a w komentarzu CKE podkreślono, że najczęstsze błędne odpowiedzi wynikały z braku zrozumienia polecenia. Wyraźnie w nim napisano, że należy podać dwie różnice, które dostrzegał Józef Piłsudski między działaniami spiskowymi z 1830 i 1863 r. Wielu zdajacych wymieniało różnice, które sami zauważali, bez analizy tekstu źródłowego. Natomiast należało zwrócić uwagę na postawy przywódców spisku w 1830 i 1863 r. oraz platformę społeczna, na której oparli swoją działalność spiskowcy. Znaczna

${ }^{30}$ Osiagnięcia maturzystów w 2007 r. Komentarz do zadań z historii, Warszawa, czerwiec 2007, s. 28-29, http://archiwum.cke.edu.pl/images/stories/Wyniki07mat/historia.pdf (dostęp: 20 XII 2016).

31 Arkusz. Egzamin maturalny z historii. Poziom podstawowy, maj 2008, s. 20, https://www. cke.edu.pl/images/_EGZAMIN_MATURALNY_OD_2015/Arkusze_egzaminacyjne/2008/ hist_pp.pdf (dostęp: 20 XII 2016). 
część piszących miała też problem z interpretacją tekstu, ograniczając się do jego cytowania ${ }^{32}$.

Kolejne zadanie, w którym znalazło się odwołanie do postaci J. Piłsudskiego w kontekście wydarzeń związanych z zakończeniem procesu odradzania się państwa polskiego w $1918 \mathrm{r}$., zamieszczone zostało w arkuszu podstawowym z maja 2010 r. Zadanie nr 30 zawierało fragment listu Józefa Piłsudskiego z 21 XI 1918 r.:

Drogi Panie Romanie, Wysyłając do Paryża delegację, która się ma porozumieć z Komitetem paryskim w sprawie wspólnego działania wobec aliantów, proszę Pana, aby zechciał Pan wszystko uczynić dla załatwienia rokowań. Niech mi Pan wierzy, że nade wszystko życzę sobie uniknięcia podwójnego przedstawicielstwa Polski wobec aliantów: tylko jedno wspólne przedstawicielstwo może sprawić, że nasze żądania zostaną wysłuchane. [...] Opierając się na naszej starej znajomości, mam nadzieję, że w tym wypadku i w chwili tak poważnej, co najmniej kilku ludzi - jeśli nie cała Polska - potrafi się wznieść ponad interesy partii, klik i grup. Chciałbym bardzo widzieć Pana między tymi ludźmi. Proszę przyjąć zapewnienia mojego wysokiego szacunku³3.

$\mathrm{Na}$ podstawie tekstu uczniowie mieli określić jego adresata oraz podać nazwę ruchu (nurtu) politycznego, do którego należał. Z pierwszą częścią, czyli wskazaniem Romana Dmowskiego, poradziła sobie zdecydowana większość zdajacych (80\%). Zapewne pomocne było podanie na początku listu jego imienia. Znacznie gorzej wypadła odpowiedź na drugie pytanie, gdzie poprawnej odpowiedzi (ruch narodowy/ wszechpolski) udzieliło tylko 33\% maturzystów ${ }^{34}$.

W $2012 \mathrm{r}$. w arkuszu maturalnym dla poziomu rozszerzonego w zadaniu nr 25 uczniowie mieli wybrać jeden z dwóch podanych tematów i napisać wypracowanie. Drugi temat wręcz idealnie pasuje do problematyki niniejszego artykułu - „Dwie drogi do niepodległości. Przedstaw i oceń zasługi Romana Dmowskiego i Józefa Piłsudskiego dla odzyskania wolności przez Polskę" ${ }^{35}$. W omówieniu prac uczniów, dokonanym przez pracowników CKE, zwrócono uwagę, że tematy wypracowań maturalnych, które dotyczyły roli jednostki $\mathrm{w}$ historii (pierwszy temat odnosił się do oceny dokonań Aleksandra Wielkiego i jego wpływu na dzieje), choć nie były trudne, sprawiły uczniom sporo

${ }^{32}$ Osiagnięcia maturzystów w roku 2008. Sprawozdanie z egzaminu maturalnego w maju 2008 roku, s. 100, https://www.cke.edu.pl/images/_EGZAMIN_MATURALNY_OD_2015/ Informacje_o_wynikach/2008/spr_humanist_a.pdf (dostęp: 20 XII 2016).

${ }^{33}$ Arkusz. Egzamin maturalny z historii. Poziom podstawowy, maj 2010, s. 20, https://www. cke.edu.pl/images/_EGZAMIN_MATURALNY_OD_2015/Arkusze_egzaminacyjne/2010/ Historia/historia_pp.pdf (dostęp: 20 XII 2016).

${ }^{34}$ Osiagnięcia maturzystów w roku 2010. Sprawozdanie z egzaminu maturalnego w maju 2010 roku, s. 35, https://www.cke.edu.pl/images/_EGZAMIN_MATURALNY_OD_2015/ Informacje_o_wynikach/2010/raport_matura_2010.pdf (dostęp: 20 XII 2016).

${ }^{35}$ Arkusz. Egzamin maturalny z historii. Poziom podstawowy, maj 2012, s. 19, https://www. cke.edu.pl/images/_EGZAMIN_MATURALNY_OD_2015/Arkusze_egzaminacyjne/2012/maj/ hist/historia_pr.pdf (dostęp: 20 XII 2016). 
trudności. Egzaminatorzy zauważyli, że przeważały prace kalendarzowo-odtwórcze, zawierające faktografię. Wielu maturzystów, spośród tych, którzy wybierali temat drugi, skupiło uwage na faktach związanych z życiem i działalnością Józefa Piłsudskiego. Opisywano dość szczegółowo jego zasługi dla Polski i Polaków, jako twórcy Legionów, Naczelnika Państwa i wodza $\mathrm{w}$ wojnie $\mathrm{z}$ bolszewikami, a następnie przechodzono do przedstawienia przejęcia władzy w 1926 r. Natomiast działalność Romana Dmowskiego często sprowadzano do stwierdzenia, że - jako przywódca endecji - był przeciwnikiem Piłsudskiego. Wiedzę o dwóch drogach do niepodległości eksponowano niedostatecznie. „Na ogół - jak podkreślono - ograniczano się do zdawkowych wyjaśnień i nie rozwijano zagadnienia. Wielu piszących miało problem z usytuowaniem rozważań w czasie, przez co przesuwali ramy czasowe po rok 1935, a nawet 1939. Przy realizacji obu tematów, maturzyści, chcąc spełnić kryterium odwołania się do ocen historiograficznych, powoływali się na autorów podręczników, a niekiedy nawet poprzestawali tylko na wymienieniu nazwisk autorów"36.

Kolejne zadanie na maturze $\mathrm{z}$ historii, w którym w kontekście walki o niepodległość Polski podczas I wojny światowej pojawił się J. Piłsudski, odnajdujemy w arkuszu podstawowym z maja $2014 \mathrm{r}$. W zadaniu nr 30 zamieszczono dwa teksty źródłowe. Pierwszy to fragment Odezwy wielkiego księcia Mikołaja Mikołajewicza z 14 VIII 1914 r., zaś drugi dokument to fragment Pamiętnika Ignacego Daszyńskiego. I właśnie w tekście jednego z liderów polskiego ruchu socjalistycznego odnajdujemy passus poświęcony Piłsudskiemu:

W połowie sierpnia 1914 roku Polska weszła w wir wojny światowej rozdwojona [...]. Polacy musieli walczyć z Polakami za cele nie polskie, lecz rosyjskie, pruskie, austriackie. W okopach wrogich armii strzelali do siebie żołnierze polscy [...]. Rzeka krwi polskiej miała się polać bezimiennie, bez celu polskiego. Tylko garść [żołnierzy] Piłsudskiego wywiesiła śmiało sztandar niepodległej Polski, ona jedna nie taiła swoich zamiarów, ona jedna była przekonana, że trudzi się i umiera za Polskę ${ }^{37}$.

Do tekstów ułożono pięć pytań. W ostatnim poproszono uczniów, aby wyjaśnili, w jaki sposób Daszyński ocenił inicjatywę Piłsudskiego ${ }^{38}$. Polecenie prawidłowo wykonało $74 \%$ uczniów.

W ostatnich dwóch latach (2015-2016) arkusze maturalne, opracowane według nowych zasad, co było m.in. konsekwencją nowej podstawy programowej,

${ }^{36}$ Osiagnięcia maturzystów w roku 2012. Sprawozdanie z egzaminu maturalnego w maju 2012 roku, s. 36, https://www.cke.edu.pl/images/_EGZAMIN_MATURALNY_OD_2015/ Informacje_o_wynikach/2012/2012_Matura.pdf (dostęp: 20 XII 2016).

37 Arkusz. Egzamin maturalny z historii. Poziom podstawowy, maj 2014, s. 22, https://www. cke.edu.pl/images/_EGZAMIN_MATURALNY_OD_2015/Arkusze_egzaminacyjne/2014/ historia_PP_A1.pdf (dostęp: 20 XII 2016).

${ }^{38}$ Ibidem, s. 23. 
nie zawierały zadań odwołujących do postaci Józefa Piłsudskiego. Komendant pojawił się jednak w kilku innych zadaniach maturalnych w arkuszach z lat 2006-2014. Nie omawiam ich tutaj, gdyż odnoszą się do II Rzeczypospolitej, a więc okresu, którego nie dotyczy prezentowany tekst ${ }^{39}$. Dowodzi to jednoznacznie, że na poziomie ponadgimnazjalnym postać J. Piłsudskiego cieszyła się wśród autorów zadań maturalnych oraz ekspertów CKE dużą popularnością. Warto w tym miejscu zwrócić uwagę, że częstotliwość pojawiania się określonych wydarzeń i postaci w arkuszach egzaminów zewnętrznych w znaczący sposób wpływa na ich popularyzację. Wiąże się to m.in. z wykorzystywaniem arkuszy z poprzednich lat w przygotowaniach do egzaminów kolejnych roczników maturzystów. Nie bez znaczenia jest tu wspomniana już łatwość $\mathrm{w}$ dostępie do arkuszy poprzez stronę internetowa CKE. Z tego też względu w prezentowanej analizie wykorzystane zostały tylko te arkusze, które młodzież rozwiązywała na maturze, a każda zainteresowana osoba może zweryfikować. Należy jednak pamiętać, że od wielu lat propozycje zadań maturalnych, w tym również odwołujących się do działalności J. Piłsudskiego podczas I wojny światowej, przygotowuja prywatne wydawnictwa edukacyjne.

Nie sposób tu pominacć negatywnej tendencji, jaką był wyraźny spadek maturzystów wybierających w kolejnych latach, począwszy od 2005 r., historię jako przedmiot maturalny. Wymownie oddaja to statystyki, według których do egzaminu maturalnego z historii w całej Polsce przystapiło ogółem 68160 abiturientów, co stanowi $22,1 \%$ wszystkich maturzystów. Historię jako przedmiot obowiązkowy wybrało 57545 osób, czyli 84,4\% ogólnej liczby zdających ten przedmiot, a jako dodatkowy - 10615 (15,6\%) maturzystów. Spośród ogółu maturzystów, którzy zdecydowali się na historię jako przedmiot obowiązkowy, $66,11 \%$ zdawało ja na poziomie rozszerzonym. W podsumowaniu analizy członkowie CKE napisali, że „Historia jest jednym z najczęściej wybieranych przedmiotów na egzaminie maturalnym" ${ }^{40}$. W maju $2006 \mathrm{r}$. do egzaminu maturalnego z historii przystapiło 68697 osób, czyli 17,1\% wszystkich zdających maturę ${ }^{41}$. Rok później było to już tylko $14 \%{ }^{42}$. W 2008 r. liczba spadła

${ }^{39}$ Zob. arkusze z 2006 r. (poziom podstawowy, zadanie nr 29), 2008 (poziom podstawowy, zadanie $\mathrm{nr}$ 30), 2011 (poziom podstawowy, zadanie $\mathrm{nr} 27$ ), 2012 (poziom podstawowy, zadanie $\mathrm{nr}$ 26), 2013 (poziom podstawowy, zadanie $\mathrm{nr} 26$ ), 2014 (poziom podstawowy, zadanie nr 32).

${ }^{40}$ Sprawozdanie o wynikach egzaminu maturalnego. Matura 2005. Przedmioty humanistyczne, s. 45, 67, http://archiwum.cke.edu.pl/images/stories/Wyniki/humanistyczny.pdf (dostęp: 20 XII 2016).

${ }^{41}$ Sprawozdanie o wynikach egzaminu maturalnego. Matura 2006. Przedmiotu humanistyczne, s. 57, http://archiwum.cke.edu.pl/images/stories/Matura2006wyniki/raport_hum. pdf (dostęp: 20 XII 2016).

${ }^{42}$ Osiagnięcia maturzystów w roku 2007. Sprawozdanie z egzaminu maturalnego, s. 159, https://www.cke.edu.pl/images/_EGZAMIN_MATURALNY_OD_2015/Informacje_o_wynikach/2007/sprawozdanie_ogolne_a.pdf (dostęp: 20 XII 2016). 
do $11 \%{ }^{43}$. W 2009 r. było to już niespełna 9\% ${ }^{44}$. Punkt krytyczny, jak się wydawało, historia osiagnęła w 2010 r., gdy spadła na szóste miejsce wśród wybieranych przedmiotów. W deklaracji maturalnej wskazało ją nieco ponad 7,5\% i wyprzedziła już tylko historię sztuki czy informatykę ${ }^{45}$. Okazało się jednak, że mogło być jeszcze gorzej, gdyż w 2011 r. historię wybrało 6,6\% maturzystów $^{46}$. Tendencja spadkowa została utrzymana w 2012 r., gdy historię na poziomie podstawowym lub rozszerzonym wybrało $6,2 \%$ zdających $^{47}$ oraz w 2013 r., gdy na ogólną liczbę 326602 ubiegających się o świadectwo dojrzałości jako przedmiot dodatkowy historię zdawało 18 763, co stanowiło 5,7\% maturzystów ${ }^{48}$. Jak dotychczas najgorszy był 2014 r., gdy w całym kraju do matury z historii przystapiło 16046 z 293974 uczniów, czyli 5,5\% ogółu maturzystów ${ }^{49}$. Systematyczny spadek uczniów wybierających historię jako przedmiot zdawany na maturze zatrzymało wprowadzenie w 2015 r. nowej formuły egzaminu. Egzamin zdecydowało się wówczas zdawać 17328 osób ${ }^{50}$. Ostatni egzamin w maju 2016 r. potwierdził pozytywny trend. Spośród 258372 abiturientów maturę z historii zdawało 19 073, co stanowi blisko 7,4\% zmieniło to jednak pozycji historii jako przedmiotu, który w wyborach uczniów klas maturalnych zajmuje dopiero szóste miejsce i przegrywa z geografia, biologia, chemia, wiedzą o społeczeństwie oraz fizyka. Celowo pozwoliłem

${ }^{43}$ Osiagnięcia maturzystów w roku 2008. Sprawozdanie z egzaminu maturalnego w maju 2008 roku, s. 12, https://www.cke.edu.pl/images/_EGZAMIN_MATURALNY_OD_2015/ Informacje_o_wynikach/2008/sprawozdanie_ogolne_a.pdf (dostęp: 20 XII 2016).

${ }^{44}$ Osiagnięcia maturzystów w roku 2009. Sprawozdanie z egzaminu maturalnego w maju 2009 roku, s. 63, https://www.cke.edu.pl/images/_EGZAMIN_MATURALNY_OD_2015/ Informacje_o_wynikach/2009/raport_matura_2009.pdf (dostęp: 20 XII 2016).

${ }^{45}$ Osiagnięcia maturzystów w roku 2010. Sprawozdanie z egzaminu maturalnego w maju $2010 \mathrm{roku}$, s. 7, https://www.cke.edu.pl/images/_EGZAMIN_MATURALNY_OD_2015/ Informacje_o_wynikach/2010/raport_matura_2010.pdf (dostęp: 20 XII 2016).

${ }^{46}$ Osiagnięcia maturzystów w roku 2011. Sprawozdanie z egzaminu maturalnego w maju $2011 \mathrm{roku}$, s. 8, https://www.cke.edu.pl/images/_EGZAMIN_MATURALNY_OD_2015/ Informacje_o_wynikach/2011/raport_2011.pdf (dostęp: 20 XII 2016).

${ }_{47}$ Osiagnięcia maturzystów w roku 2012. Sprawozdanie z egzaminu maturalnego w maju 2012 roku, s. 7, https://www.cke.edu.pl/images/_EGZAMIN_MATURALNY_OD_2015/ Informacje_o_wynikach/2012/2012_Matura.pdf (dostęp: 20 XII 2016).

${ }^{48}$ Osiagnięcia maturzystów w roku 2013. Sprawozdanie z egzaminu maturalnego w maju 2013 roku, s. 5-7, https://www.cke.edu.pl/images/_EGZAMIN_MATURALNY_OD_2015/ Informacje_o_wynikach/2013/2013_Matura.pdf (dostęp: 20 XII 2016).

${ }^{49}$ Osiagnięcia maturzystów w roku 2014. Sprawozdanie z egzaminu maturalnego w maju 2014 roku, s. 5, https://www.cke.edu.pl/images/_EGZAMIN_MATURALNY_OD_2015/Informacje_o_wynikach/2014/sprawozdanie/Raport_og\%C3\%B3lny.pdf (dostęp: 20 XII 2016).

50 Sprawozdanie ogólne z egzaminu maturalnego 2015, s. 7, https://www.cke.edu.pl/images/_EGZAMIN_MATURALNY_OD_2015/Informacje_o_wynikach/2015/sprawozdanie/ Sprawozdanie_ogolne_2015.pdf (dostęp: 20 XII 2016).

51 Sprawozdanie ogólne z egzaminu maturalnego 2016, s. 3, 6, https://www.cke.edu.pl/ images/_EGZAMIN_MATURALNY_OD_2015/Informacje_o_wynikach/2016/sprawozdanie/ Sprawozdanie_ogolne_2016.pdf (dostęp: 20 XII 2016). 
sobie przytoczyć to dłuższe zestawienie statystyczne, gdyż stanowi ono jedną z przyczyn obniżającego się poziomu ogólnej wiedzy historycznej polskiego społeczeństwa, a w szczególności uczniów kończących w ostatnich latach szkoły ponadgimnazjalne. To z kolei znajduje swoje odzwierciedlenie w poziomie wiedzy kolejnych roczników studentów na kierunkach społeczno-humanistycznych.

Podsumowując, należy raz jeszcze podkreślić znaczenie treści historycznych, z którymi uczniowie stykają się na kończących poszczególne etapy edukacji egzaminach zewnętrznych. Aktualnie dotyczy to w Polsce uczniów klasy VI szkoły podstawowej (do kwietnia 2016), klasy III gimnazjum (do kwietnia 2019) oraz klas maturalnych szkół ponadgimnazjalnych. W tym kontekście obecność Józefa Piłsudskiego i to tylko w odniesieniu do wydarzeń z I wojny światowej, gdy jego droga do wolnej Polski była już na ostatniej prostej, wydaje się satysfakcjonujacca. Naturalnie osoby, którym postać Komendanta jest szczególnie bliska, mogą czuć pewien niedosyt. Powinny jednak pamiętać, że zadania egzaminacyjne $\mathrm{z}$ historii nie mogą być zdominowane przez jedna postać, nawet wówczas, gdy jest nią taka osoba, jak Józef Piłsudski.

\section{Streszczenie}

Prezentowany artykuł zawiera analizę obrazu Józefa Piłsudskiego w zadaniach $\mathrm{z}$ historii, przygotowywanych na potrzeby ogólnopolskich egzaminów zewnętrznych przez Centralna Komisję Egzaminacyjna. W pierwszej części przeanalizowane zostały zadania z arkuszy gimnazjalnych, w drugiej - maturalnych. Analiza wykazała satysfakcjonująca obecność Józefa Piłsudskiego w zadaniach odnoszących się do wydarzeń z I wojny światowej, gdy jego droga do wolnej Polski była już na ostatniej prostej. Naturalnie osoby, którym postać Komendanta jest szczególnie bliska, mogą czuć pewien niedosyt. Powinny jednak pamiętać, że zadania egzaminacyjne $\mathrm{z}$ historii nie mogą być zdominowane przez jedną postać.

\section{Józef Piłsudski's "road to independence" in the historical awareness of young people (on the example of exercises on history in external exams worksheets)}

The article presents an analysis of Józef Piłsudski’s image seen in exercises on history prepared for the national Polish internal exams by the Central Examination Commission. The first part of the study contains an analysis of junior high school worksheets, and the second -the worksheets of the high school finals. The analysis reveals a satisfactory presence of Józef Piłsudski in exercises on events of the First World War, when he was in the home stretch of his way to the independent Poland. Naturally, the people to whom Piłsudski is especially close, might feel slightly unsatisfied, but they should bear in mind that history examinations cannot be dominated by one personage.

\section{Bibliografia}

Anusiewicz-Działak B., Informator o maturze 2005, „Wiadomości Historyczne” 2004, nr 1, s. $53-55$.

Anusiewicz-Działak B., Matura z historii w 2005 roku, „Wiadomości Historyczne” 2003, nr 5, s. 36-41. 
Białokur M., Józef Piłsudski i jego rola w tworzeniu niepodległościowego ruchu wojskowego na kartach wybranych podręczników szkolnych, w: Zwiazek Strzelecki „Strzelec”- organizacja społeczno-wychowawcza. Między tradycja a wspótczesnościa, red. A. Adamczyk, Zelów 2006, s. 165-183.

Białokur M., Piłat J., Stecka K., Historia $i$ WOS na maturze, czyli pedagoga szkietko i oko, „Wiadomości Historyczne” 2007, nr 2, s. 13-24.

Bieniek M., Dydaktyka historii. Wybrane zagadnienia, Olsztyn 2009.

Chomicki G., Historia powróci do zdrowia, czyli nie reformujmy reformy, „Wiadomości Historyczne" 2005, nr 1, s. 47-54.

Chorąży E., Konieczka-Śliwińska D., Roszak S., Edukacja historyczna w szkole. Teoria i praktyka, Warszawa 2008.

Durka J., Rola postaci historycznych w edukacji - dotychczasowe doświadczenia a „nowa podstawa programowa z historii”, w: Pamięć, kultura, edukacja, red. nauk. A.P. Bieś, M. Chrost, B. Topij-Stempińska, Kraków 2011, s. 123-133.

Jakubowska B., Metodologia w sojuszu z egzaminem maturalnym, „Wiadomości Historyczne” 2006, nr 1, s. 30-36.

Jakubowska B., Przeobrażenia w szkolnej edukacji historycznej $w$ Polsce $w$ latach 1944-1956, Warszawa 1986.

Kusiak P., Legenda Józefa Pitsudskiego. Jak w Polsce doby integracji europejskiej interpretować postać Marszatka?, „Colloquium” R. II, 2010.

Maternicki J., Majorek C., Suchoński A., Dydaktyka historii, Warszawa 1994.

Nauczyciel historii. Ku nowej formacji dydaktycznej, red. M. Kujawska, Poznań 1996.

Okulewicz P., Józef Pitsudski - między popularnościa a kultem, „Wiadomości Historyczne z Wiedzą o Społeczeństwie" 2006, nr 5, s. 18-28.

Rulka J., Przemiany świadomości historycznej młodzieży, Bydgoszcz 1991.

Rulka J., Świadomość historyczna młodzieży przetomu tysiacleci - wybrane zagadnienia, w: $Z \dot{Z}$ ywca do Opola. Góral z urodzenia, opolanin z wyboru, red. B. Kubis, Opole 2011, s. $349-357$.

Składanowski H., „Od uwielbienia do negacji” - Józef Pitsudski w podręcznikach historii $w$ szkole powszechnej (podstawowej) w II RP i okresie stalinowskim PRL, „Wiadomości Historyczne z Wiedzą o Społeczeństwie” 2006, nr 5, s. 30-38.

Suchoński A., Białokur M., Przewrót majowy Józefa Piłsudskiego w podręcznikach szkolnych, „Wiadomości Historyczne z Wiedzą o Społeczeństwie” 2007, nr 3, s. 17-40.

Suchoński A., Polacy na kartach zagranicznych podręczników do nauczania historii, w: Polska, Europa, świat w szkolnych podręcznikach historii, red. S. Roszak, M. Strzelecka, A. Wieczorek, seria: „Toruńskie Spotkania Dydaktyczne”, t. V, Torun 2008, s. 10-18.

Suchoński A., Postać Józefa Piłsudskiego w podręcznikach szkolnych, w: Józef Piłsudski i jego wspótpracownicy, red. A. Suchoński, Opole 1999, s. 139-149.

Wójcik-Łagan H., Kult bohatera narodowego Józefa Piłsudskiego w szkolnej edukacji historycznej $w$ latach trzydziestych XX wieku, Kielce 2012.

Wspótczesna dydaktyka historii. Zarys encyklopedyczny dla nauczycieli i studentów, red. J. Maternicki, Warszawa 2004.

Zielecki A., Role i funkcje podręcznika historii, Rzeszów 1984.

Zielecki A., Wprowadzenie do dydaktyki historii, Kraków 2007.

Biog r a m: Marek Białokur - dr hab., adiunkt w Katedrze Historii Najnowszej Instytutu Historii Uniwersytetu Opolskiego, nauczyciel historii w Zespole Szkół Ogólnokształcacych w Opolu, członek Polskiego Towarzystwa Historycznego Oddział w Opolu (przewodniczący sekcji dydaktycznej). Zainteresowania naukowe: biografistyka XX wieku, historia polskiej myśli politycznej XX wieku, dydaktyka historii. E-mail: mbialokur@uni.opole.pl. 